Portland State University

PDXScholar

\title{
Comparisons of Current Practices of Computer Use and Training by Industry Type of Small Businesses in the Portland Area
}

Don Gregory Langenhorst

Portland State University

Follow this and additional works at: https://pdxscholar.library.pdx.edu/open_access_etds

Part of the Business Administration, Management, and Operations Commons, and the Entrepreneurial and Small Business Operations Commons

Let us know how access to this document benefits you.

\section{Recommended Citation}

Langenhorst, Don Gregory, "Comparisons of Current Practices of Computer Use and Training by Industry Type of Small Businesses in the Portland Area" (1989). Dissertations and Theses. Paper 3910.

https://doi.org/10.15760/etd.5794

This Thesis is brought to you for free and open access. It has been accepted for inclusion in Dissertations and Theses by an authorized administrator of PDXScholar. Please contact us if we can make this document more accessible: pdxscholar@pdx.edu. 
AN ABSTRACT OF THE THESIS OF Don Gregory Langenhorst for the Master of Science in Teaching in Business Education presented January 4, 1989.

Title: Comparisons of Current Practices of Computer Use and Training by Industry Type of Small Businesses in the Portland Area.

APPROVED BY MEMBERS OF THE THESIS COMMITTEE:
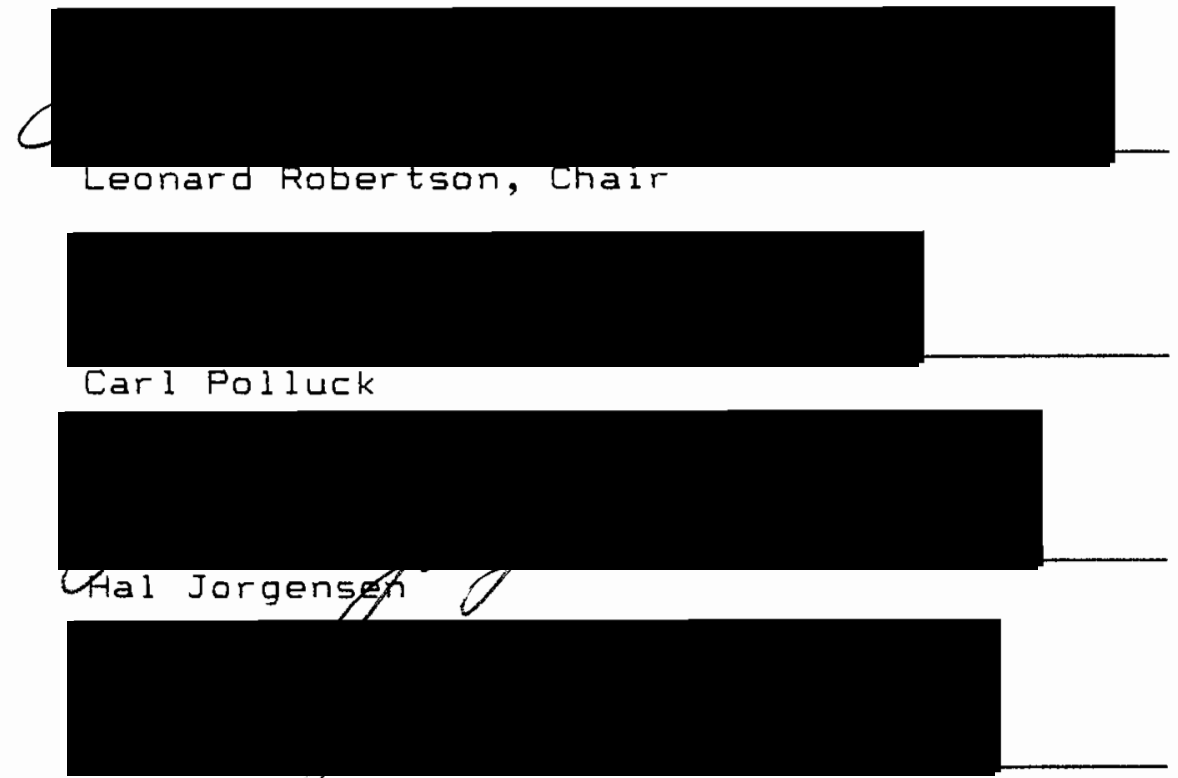

Amy Dristoll

The problem was to determine what are the current computer uses, and training practices for small businesses in the Portland area. Comparisons were made by industry type.

Data was collected from a mailed questionnaire. Two survey mailings were conducted. A total of 558 of the 2,490 
businesses surveyed responded, yielding a $22.4 \%$ response rate.

Approximately $75 \%$ used microcomputers, $17 \%$

minicomputers and $8 \%$ used mainframe computers. Percentage use of different size computer systems was determined for each industry type.

Using the most common six brands of systems it was determined that businesses do not use similar brands of machines. The survey does not attempt to group brands as compatible.

In comparing uses of software, two groupings were used, custom and commercial. Each of these areas was further divided in two. Of the 118 businesses using custom software, $77.1 \%$ reported using software written for their type of business. A total of 428 businesses reported using some type of commercial software; $35.7 \%$ reported using single task software and $64.3 \%$ using multiple task software.

Different industry types do not use similar size computers, brands of computers, or similar classifications of software. Small businesses of different industry type do not use similar computer equipment.

The uses of computer equipment was grouped into $5 \mathrm{ix}$ areas. Based on the large groupings it can be inferred that industry types use computer equipment for similar general tasks. 
Each of the general areas were divided according to particular tasks relevant to the grouping. Analysis by the particular task yielded different results. No significant similarities in the particular accounting, word processing, records management, marketing, financial planning, and inventory and database handling tasks can be inferred. Based on these findings small businesses of different industry type do not use computer equipment for similar tasks.

The final area of analysis was training provided operators. A total of 3,930 computer operators were represented. The mean number of operators per business was slightly above 7, the mode was 2 , and the range from 1 to 70. Operators in different industry types have similar formal educational backgrounds. Also operators have similar training when analyzed by length of courses. The last area was from whom operators received training. It can be inferred that operators received training from similar sources. All three areas yielded similar results. There are no significant differences in the training provided operators working in small businesses when compared by industry type. 
COMPARISONS OF CURRENT PRACTICES OF COMPUTER USE AND TRAINING BY INDUSTRY TYPE OF SMALL BUSINESSES IN THE PORTLAND AREA

\author{
by
}

DON GREGORY LANGENHORST
A thesis submitted in partial fullfillment of the requirements for the degree of

\author{
MASTER OF SCIENCE IN TEACHING \\ in \\ BUSINESS EDUCATION
}

Portland State University

1989 
TO THE OFFICE OF GRADUATE STUDIES:

The members of the Committee approve the thesis of Don Gregory Langenhorst presented January 4, 1989.

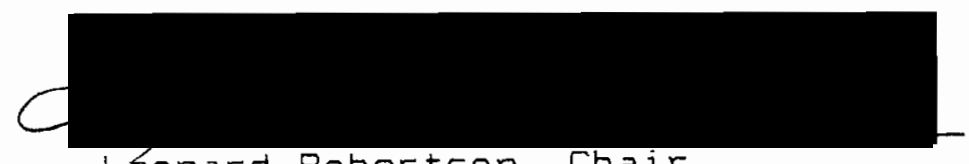

Leonard Robertson, Chair

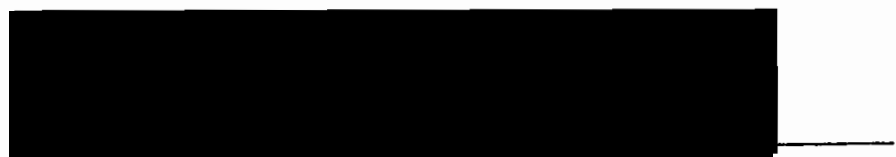

$$
\text { Carl Polluck }
$$

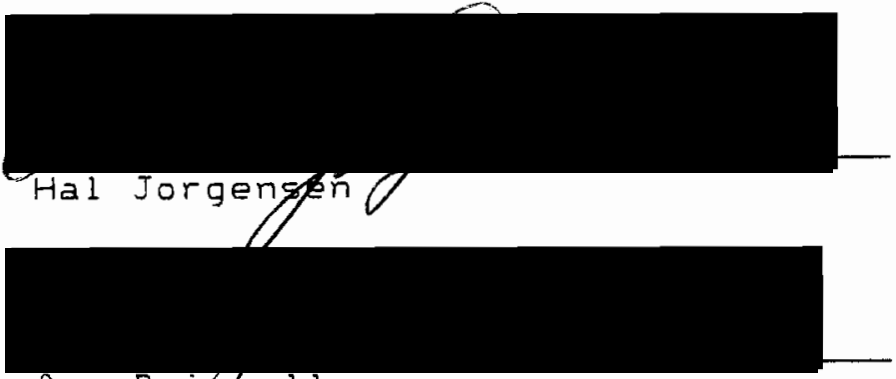

Amy Driktol1

APPRDVED :
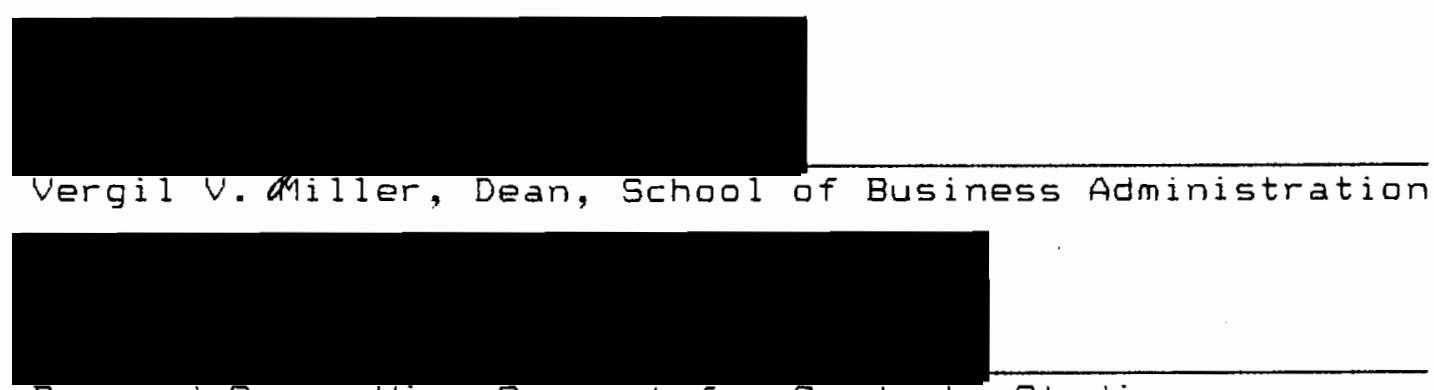
TABLE OF CONTENTS

PAGE

LIST OF TABLES

$\vee \mathfrak{i}$

LIST OF FIGURES

vii

CHAPTER

I THE PROBLEM AND ITS SETTING - . • . . . . . . . . . . . 1

The Statment of Problem . . . . . . . . . 1

Subproblems . . . . . . . . . . . . . . . 1

Hypotheses • . • . . . . . . . . . . . . . 1

The Delimitations . . . . . . . . . . e

The Definition of Terms . . . . . . . . 2

The Importance of the Study . . . . . . . . 4

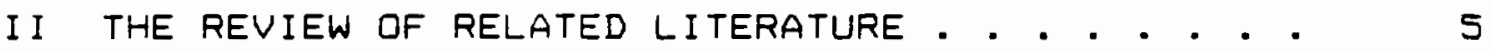

Historical Overview . . . . . . . . . . 5

Personal Computers Become Popular . . . . 6

Equipment Used . . . . . . . . . . . . . 7

Equipment Uses . . . . . . . . . . . . 7

Training . . . . . . . . . . . . . . . 8

I I I PROCEDURES FOR THE GATHERING AND TREATMENT OF DATA 11

Research Design . . . . . . . . . . . . . 11

Methodology . . . . . . . . . . . . . . 11

Sampling Design . . . . . . . . . . . . . . 11

Questionnarie Design . . . . . . . . . 12 
Statistical Analysis . . . . . . . . . 13

Specific Treatment of Data of Each Subproblem 13

IV. RESULTS . . . . . . . . . . . . . . . . . . . . 16

Analysis of Non-Response . . . . . . . . 18

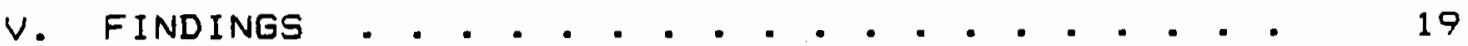

A. COMPUTER EQUIPMENT . - . . . . . . . . 19

Size of Computers . . . . . . . . 19

Brands of Computers . . . . . . 20

Software Types . . . . . . . . . 22

B. COMPUTER TASKS . . . . . . . . . . . . . 25

Accounting . . . . . . . . . . . 25

Word Processing . . . . . . . . 26

Records Management . . . . . . . 27

Marketing . . . . . . . . . . . . 28

Financial Planning . . . . . . . . . 29

Inventory and Data Base Handling . . 30

C. TRAINING PROVIDED COMPUTER OPERATORS • - 32

Educational Background . . . . . . 32

Specific Training . . . . . . . . 33

Instructors of Operators..... . 34

VI. CONCLUSION AND RECOMMENDATIONS . . . . . . . . . . 36

Rejection of First Hypothesis. . . . . . 36

Rejection of Second Hypohesis . . . . . . 36

Acceptance of Third Hypothesis . . . . . . 37 
Discussion . . . . . . . . . . . . . . .

Recommendations for Further Research . . .

BIBLIOGRAPHY . . . . . . . . . . . . . . . . . . . . . . . 41

APPENDIX A . . . . . . . . . . . . . . . . . . . . . . . . . . . 44

APPENDIX B . . . . . . . . . . . . . . . . . . . . . . . . . 45

APPENDIX $\mathrm{C}$. . . . . . . . . . . . . . . . . . . . . . . . . . 46

APPENDIX D . . . . . . . . . . . . . . . . . . . . . . . . . . . . . . 47

APPENDIX E . . . . . . . . . . . . . . . . . . . . . . . . . . 50 


\section{LIST OF TABLES}

TABLE

PAGE

I Stratified Response Results . . . . . . . 16

I Rate of Return on First Mailing . . . . . 17

II Rate of Return on Second Mailing....... 18 


\section{LIST OF FIGURES}

FIGURE

PAGE

1. Size of computers . . . . . . . . . . . . 20

2. Six major brands . . . . . . . . . . . 21

3. Types of software . . . . . . . . . . . . 23

4. Grouped by tasks . . . . . . . . . . . . . 24

5. Accounting . . . . . . . . . . . . . . . 26

6. Word processing . . . . . . . . . . . . 27

7. Records management . . . . . . . . . . . . 28

8. Marketing . . . . . . . . . . . . . . . . 29

9. Financial planning . . . . . . . . . . . 30

10. Inventory and data base handling . . . . . . 31

11. Educational background . . . . . . . . . . 33

12. Specific training . . . . . . . . . . . 34

13. Instructors of operators . . . . . . . . 35 
CHAPTER I

THE PROBLEM AND I.TS SETTING

The Statement of Problem

The problem is to determine the current uses of computers and the training provided operators by a representative sample of small businesses in the Portland area. Comparisons will be made by industry type.

\section{Subproblems}

The first subproblem. The first subproblem is to determine what computer equipment is currently in use by small businesses.

The second subproblem. The second subproblem is to determine for what tasks small businesses use the computers. The third subproblem. The third subproblem is to determine what training was provided operators in the use of the equipment.

\section{Hypotheses}

The first hypothesis is that there is no significant differences in the computer equipment used by small businesses in the fortland area when they are compared by industry. 
The second hypothesis is that there is no significant differences in the kind of tasks performed on computers by small businesses in the Portland area when they are compared by industry.

The third hypothesis is that there is no significant differences in the the training of compter operators by small businesses in the Portland area when they are compared by industry.

The Delimitations

This study will not attempt to identify, evaluate or predict reasons for computer selection or use.

This study will not attempt to identify, evaluate or predict success of training of computer operators.

\section{The Definition of Terms}

Computer equipment. Computer equipment is the hardware and any firmware or software needed to make use of that hardware.

Industry types. Industry types. Industry types are defined as the five categories that follow:

1. Non-Manufacturing (S.I.C. major classifications 1-17).

2. Manufacturing (S.I.C. major Classifications 20-39).

3. Service (S.I.C. major classifications 40-49, $60-89)$ 
4. Wholesale (S.I.C. major classifications $50-51)$.

5. Retail (S.I.C. major classifications 52-59).

Similar computer equipment. Similar computer equipment is computer equipment having the same size classification (mainframe, mini, or micro) and the same brand name.

Similar tasks. Similar tasks are grouped as follows:

1. Accounting (ledger, financial statements).

2. Word processing (letters, documents, mail lists).

3. Marketing (sales, forecasts, promotion).

4. Personnel/Customer Records.

5. Financial planning.

6. Inventory/Database handling.

Small business. Small business is any nonmanufacturing, service, wholesale or retail business employing 50 or fewer employees and any manufacturing business employing 100 or fewer employees.

Portland area. The Fortland area shall encompass the area: North of the Tualatin and Clackamas Rivers; south of the Columbia River; east of/and including the area of Aloha and the city of Hillsboro; west of/and including the cities of Boring, Gresham and Troutdale. In addition it also includes the cities of Vancouver, Washington and Oregon City, Oregon. 
The Importance of the Study

Previous research has been general in nature as to the computer equipment used, tasks the systems are used for and training operators receive. The little that is known does not compare different types of businesses or try to distinguish uses by different types of businesses.

Research in this area will aid entrepreneurs seeking information in selecting equipment and in updating execution of some jobs. Software can be written that is more flexible in the performance of some duties.

The research could show the lack of computer use for some tasks from which entrepreneurs might otherwise benefit. Educational programs especially adult education, could benefit from the analysis of the problem. This research will also serve as a vestige for further studies in determining rationale for computer selection and in determining training needs and effectiveness of training provided. 
CHAPTER I I

THE REVIEW OF RELATED LITERATURE

\section{Historical Qverview}

In the past small business people have not used computers mainly because of high cost. If they did decide to use computers they had the choice of using an established computer center, renting or time sharing on a large computer, or purchasing small scale equipment (26:43). In any event all were expensive and most small businesses could not afford computer use.

In 1980 computers cost firms on the average between $\$ 15,000$ - 100,000 to install (13:42). Small business are now finding it affordable to use computers. Advances in technology have lead to firms owning systems at a fraction of historical costs. A rough approximation of the decline in costs shows computer equipment that cost $\$ 100$ in 2970 , cost $\$ 10$ in 1975, cost $\$ 1$ in 1980, cost. 10 in 1985 and even less today $(10: 41)$. There does not appear to be an end in cost savings yet in sight. A flat monitor screen will make computers even more flexible, portable and cheaper (32:43). Recent technology has shown this to be true. Recent price slashing by the industry leaders and fierce competition seem 
to ensure that the lower cost for the purchase of equipment will continue.

\section{Personal Computers Become Popular}

Even before the most recent decline in prices, many small businesses were investing in the information processors. However the type of computers that most firms use has changed. The on-line mainframe computer sold primarily by Burroughs, IBM, NCR and Sperry and the minicomputers sold by Hewlett Packard and Wang were most common $(29: 43)$.

Lower costs have lead the way to what many term the "Personal Computer Revolution." The government has dropped its requirement that businesses report detailed use of personal computers for tax purposes (18:42). This has made personal computers a desirable tax break for businesses. Fewer companies are renting or leasing computer equipment, and more are purchasing equipment outright. In 1983, a survey conducted across the United States and Canada revealed 88 percent of firms used small business computers, defined as personal, desktop or microcomputers (23:42). The American Marketing Associations' survey shows an increase in the number of business people using or planning on using personal computers from 71 percent in 1982 to 96 percent in $1985(20: 42)$ 
Equigment Used

Personal computers have become the most common size computer used in small business even in Montana, a state where only 40 percent used the machines in 1982 . Two thirds of those use personal computers, the remaining one third primarily use minicomputers (9:41). An investigation in Arkansas revealed 40 different brands of microcomputers owned by businesses $(19: 42)$. In the personal computer market, International Business Machines (IBM) is by far the industry leader with 74 percent of the market. Their nearest competition is Apple Computer with market share of only 6 percent, down from 23 percent in 1984 (20:42).

Software available for small business computers is grouped into three main categories as follows: universal (package) programs, vertical programs and well-defined-niche programs. The well-defined-niche programs have served to ignite a new small business industry of software writers. Because of the unique nature of many small businesses, large companies often overlook these special needs. An example of such a niche is with firms that have large inventories like the automotive parts distributors (32:43).

\section{Equipment Uses}

Predominant uses of computer equipment in 1986 were for file management, accounting and word processing (6:41). Current trends show accounting use led the way with 69 percent of businesses using some type of computerized 
accounting system. Budgeting and forecasting is used by 76 percent, word processing 73 percent, file/records 63 percent, and instruction/training 36 percent of the firms. Little research has been done to compare the uses made of computers in particular industry types. Olive Church speculated in 1983 that entrepreneurs in small retail firms typically find microcomputers helpful for accounts receivable/billing and inventory control (4:41). In May of 1985, a Wall Street Journal report stated that 55 percent of 115,000 real estate firms used computers. Carol Lehman researched computer use with accounting, legal and medical firms in Arkansas (19:42). Among her findings were that legal firms were more likely to use word processing than other applications and that accounting firms were more likely to make complete utilization on the accounting capabilities.

\section{Training}

Books are available on how to select the correct equipment for a firm but few explain the importance of training. Of the $16.8 \mathrm{million}$ small businesses in the United States, one of the top training needs is in computer usage (17:42). The challenge of education is to develop training programs that will prepare individuals to use microcomputers more efficiently. One recent study showed 81 percent of computer operators are trained on the job with supplemental support from orientations, self-directed 
learning packets, technical workshops and faculty/commercial training $(11: 41)$.

Many entrepreneurs get caught up in the moment of the computer purchase, not realizing that the equipment is only part of the investment. Numerous stories are reported about purchases of equipment that was never utilized. The success or failure of a new system relies heavily on the installation and the training of the user (14:42).

The problem of inefficient use of expensive computer equipment may $l i e$ in the lack of good, inexpensive training. Community colleges have recently offered adult education courses in computer training. Many of these programs are set up similar to the program at Chipola Jr. College in Florida, with an introduction to many computer applications but training only in word processing (5:41). Some research has found that canned (universal/packaged) programs can be learned with short intense lessons, but these programs are not often able to meet the particular needs of the firm $(8: 41)$

Another pitfall lies with the lack of expertise of small business persons in many areas of business. Ron Seagull of Tandy's computer division sees two problems with selling computerized accounting software to small business: first, many entrepreneurs do not know computers and second, many entrpreneurs do not know accounting (1:41). 
Consultants are an expensive source for training but they are used increasingly. The largest identifiable problem with consultants seems to be with the inconsistency in the quality of the specialists. Consultants who can train the employee quickly and be available afterwards to troubleshoot are in high demand (21:42).

The entrepreneur seems reluctant to spend money on training personnel, especially for an extended period of time. This, unfortunately, does not accommodate the slow learner who is often the most productive worker $(27: 43)$. In a survey of small retail firms done by Greggory Blunbell, training ranked lowest as a primary concern in computer selection (2:41). 
CHAPTER II I

PROCEDURES FOR THE GATHERING AND TREATMENT OF DATA

\section{Research Design}

The data for the study was gathered from a two-phase mail questionnaire. The questionnaire was sent to a representative sample of small businesses in the Portland area.

\section{Methodology}

The first step was a pilot study using the draft of the main questionnaire. The purpose of this study was to determine if the instrument would yield the results that could be applied to the problem. Before the pretest questionnaire was mailed, telephone calls were made to firms asking them to assist in the pretest effort by completing the questionnaire. Twenty-five questionnaires were tested, five in each of the five industry types.

\section{Sampling Design}

A proportional stratified sampling design was used to select a sample of small businesses. The proportions were determined by the industry type percentage of all small businesses in the Portland area. The list of small businesses was obtained from Contacts Influential, an 
organization specializing in business information. This company's database contains names and addresses of all Portland area businesses. Selection of the individual businesses in each industry type was made with the aid of a computer generated random number list.

\section{Questionnaire Desian}

A cover letter was sent with the initial response card explaining the importance of the study to the firm and mention was made of the researcher's willingness to answer questions. The letter was mailed to the highest ranking official of the firm. This group included owners, managers and chief executives. The enclosed pre-addressed, stamped card (Appendix A) -- phase one -- required only a check mark and a signature by the entrepreneur. A random nonstatistical follow-up was conducted on the initial mailing to determine reasons for non-response.

In the second phase the primary information form was sent to those firms who answered the initial mailing with a positive response. A positive response was a check mark showing use of computers and willingness to complete the questionnaire. The questionnaire (Appendix B) was sent immediately upon receipt of the response card. A computerized data file was kept of questionnaires mailed with a code number to identify those returned. The code number was used to maintain confidentiality and to classify the business by industry type. 
The survey respondents were further encouraged to participate personally in the study by writing additional comments in the last section of the questionnaire.

\section{Statistical Analysis}

The objective of a sample survey is to make inferences about the population of interest based on information confined in the sample.

The sample size was determined by the following formula at a confidence level of $95 \%(z=1.96, p=.5)$.

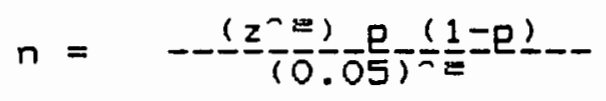

Frequency distributions and percentage of responses from participants form the basis for the descriptive tables. The chi-square test of independence at a significance level of .05 (confidence level of 95 percent) was used for the analysis of data.

Specific Treatment of Data of Each Subproblem

All data were secured from the sample of small businesses in the Portland area via the survey instrument.

Subproblem one. The first subproblem was to determine what computer equipment is currently in use by small business.

The data needed to solve the subproblem one were (a) size of computer(s) in use, (b) brand and model number of computer(s) used and (c) type of program(s) used. Types of 
programs used were identified and classified as custom and commercial software.

Treatment. Data were grouped by industry type and analyzed to determine if significant differences existed among industries in (a) size and brands of computers and (b) types of software programs used. Descriptive graphs show the frequency distribution of each classification.

Subproblem two. The second subproblem was to determine for what tasks small businesses use computers.

The data needed to solve subproblem two were the specific uses of computer equipment. Uses determined by current vendor estimation were listed in checklist form on the questionnaire.

Treatment. Data were grouped by industry type and analyzed to determine if significant differences existed among the industries in job use. The specific uses were grouped into similar tasks and a frequency distribution tabulated.

Subproblem three. The third subproblem was to determine what training was provided operators in the use of the equipment.

Data needed to solve subproblem three were the computer education background(s) of the user(s) and specific training in the use of the equipment.

Treatment. Descriptive graphs show frequency distributions of the computer education background of users 
and specific training provided operators. In addition, analysis was conducted by industry type to determine if a significant difference existed in the training operators received. 


\section{RESULTS}

The population, the number of small business in the Portland area was determined to be 48,490. A,minimum sample of 384 was needed. The percentage of the population for the business by industry type was used to determine the amount of observations needed for each of the classifications. This proportional stratified sampling design was used to determine the number of businesses surveyed. Table 1 shows the actual number of businesses, the percentage of actual businesses, the actual number of positive responses needed, the number of positive responses, and the actual percentage of positive responses by each of the industry types.

TABLE I

STRATIFIED REPONSE RESULTS

$\begin{array}{cccc}\text { Number } & \text { Percent } & \text { Sample Actual } & \text { Percent } \\ \text { of } & \text { of } & \text { Size Positive Positive } & \text { Poses } \\ \text { Businesses } & \text { Population: Negded Responses } & \text { Responses }\end{array}$

\begin{tabular}{|c|c|c|c|c|c|}
\hline Manufacturing & 3147 & $6.5 \%$ & $30 *$ & 86 & $15.5 \%$ \\
\hline Non-Manufactor ing & 4810 & $9.9 \%$ & 37 & 37 & $6.7 \%$ \\
\hline Wholesale & 5264 & $10.9 \%$ & 42 & 66 & $11.9 \%$ \\
\hline Retail & 11225 & $23.1 \%$ & 89 & 114 & $20.5 \%$ \\
\hline Service & 24044 & $49.6 \%$ & 191 & 252 & $45.4 \%$ \\
\hline
\end{tabular}

* A minimum of 30 returns was needed in each strata 
One test of representativeness of the returns is when the sample percentage in each stratum approximate the actual population percentage in each stratum.

Upon completion of the pilot study, it was determined that the questionnaires would serve adequately; therefore, the survey instrument was used as originally designed.

Two Portland area survey mailings were conducted. The first survey was mailed to 460 businesses, the positive response rate from phase one was 35\%. Questionnaires were sent to the 163 businesses that responded positively. The rate of return was $75 \%$ from the post-card phase to the return of the completed questionnaire. Based on the these percentages, the experimenter determined the size of the second survey needed at approximately 2030 . Table 2 and 3 show a breakdown of the number and percentage of returns.

\section{TABLE I I}

RATE OF RETURN ON FIRST MAILING

$$
\text { Number of }
$$
Post Cards Sent (Phase-One)
Positive

Responses from Phase-One
Completed and Valid Questionnaires

Manufacturing

50

12

Non-Manufactoring 50

Wholesale

60

10

8

Retail

100

21

16

Service

200

103

77 
TABLE I I I

RATE OF RETURN ON SECOND MAILING

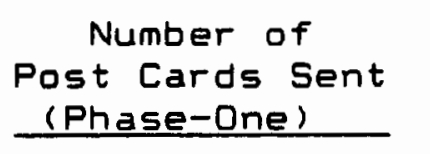

Manufacturing

Non-Manu.

Wholesale

Retail

Service

380

200

400

600

450

Positive

Responses from

Phase-One

91

68

83

126

230
Completed and Valid Questionnaires

\section{Analysis of Non-Response}

The response rates are exceptionally good as compared to many surveys in which a 20 percent return is considered average and response rates as low as 10 percent are not uncommon.

Based on the follow up information of the pilot study, there is no reason to believe that non-respondents had different $v i e w s$ to express than those who did respond. Phone calls were made to all the businesses who did not initially respond. The reasons given for non-response did not seem to indicate bias. In any case, there was no possibility to conduct a standard statistical follow-up survey of non-respondents due to the confidentiality of the mailing 1 ist. 


\section{CHAPTER IV}

\section{F IND INGS}

A total of 558 of the 2490 businesses responded with complete questionnaires, yielding a $22.4 \%$ response rate. of the 558 questionnaires, 252 were completed by service-type businesses, 117 by retail, 66 by wholesale, 86 by manufacturing and 37 by non-manufacturing, yielding $38.8 \%$, $16.7 \%, 14.3 \%, 20.0 \%$ and $14.8 \%$ of total completed questionnaires respectively. The results of the survey are summarized in the following sections.

\section{COMPUTER EQUIPMENT}

\section{Size of Computers}

Microcomputers were used by 417 of the 558 respondents (74.7 percent), 93 ( 16.7 percent) had minicomputer systems and 45 ( 8.1 percent) used mainframe computers. Figure 1 shows a percentage breakdown of the size of computers for each industry type. Mainframe computers were used by 53.3 percent of service businesses.

The chi-square test of significance $(8, N=558)=$ 24.81, $P>.01$ indicated that different industry types used different size computers. 


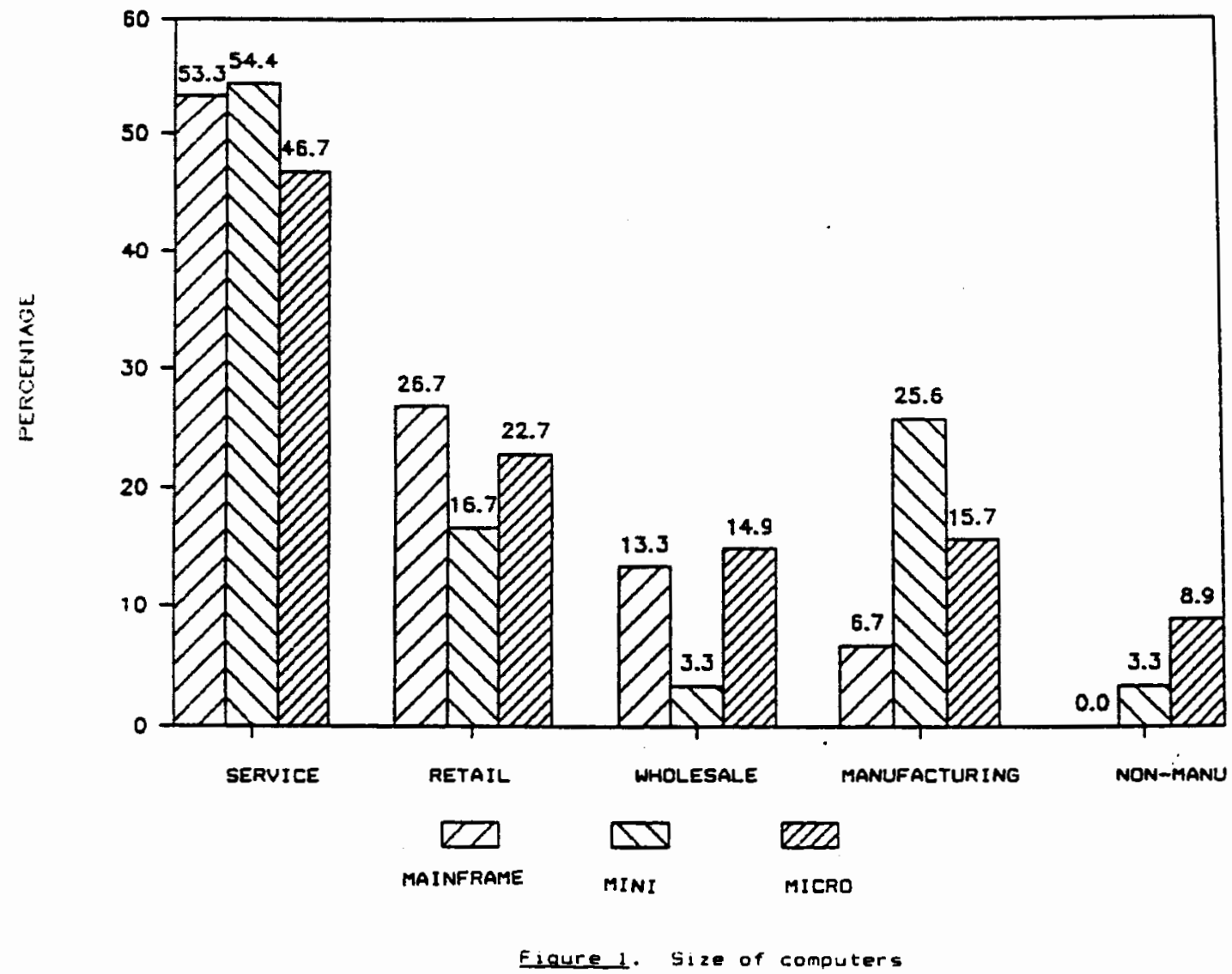

Brands of Computers

The variety of the brand names of computers is immense. The questionnaire attempted to identify the major brands in use. The majority of responses fit into six brands, yet an additional 61 brands were mentioned in the "other" category. A total of 576 computer systems were reported, 340 were either IBM, Wang, Apple, Radio Shack, Hewlett Packard or Compaq. Figure 2 shows a percentage breakdown for the $s i x$ brands by industry type. Approximately 45 percent that used IBM brand machines were service businesses and 100 percent that used Wang machines were service businesses. 


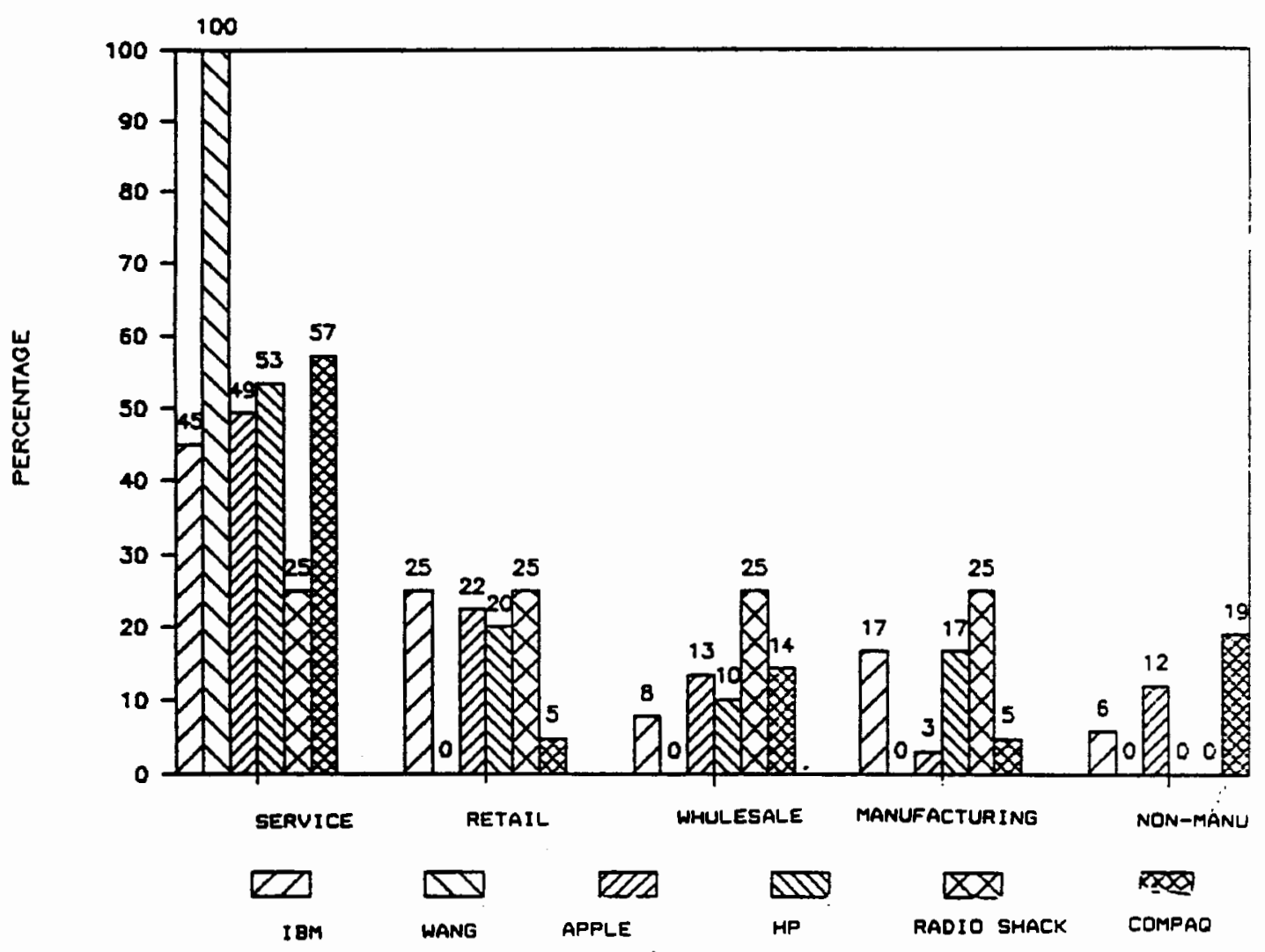

Fiqure_. Six major brands

Of the 340 "major brand" systems, 219 could be classified as MS-DOS compatible. An additional 202 of the 236 systems of the minor 61 brand names (appendix E) could also be classified as MS-DOS compatible. A total of 421 of the 576 or 73.1 percent of the systems reported were MS-DOS compatible.

It can be inferred that businesses in different industry types do not use similar brands of machines (chisquare test of significance $(8, N=558)=135.01, \mathrm{P}$ $>.001)$. The question of small business types using significantly similar MS-DOS compatible machines is beyond the scope of this study. 


\section{Software Types}

The last area analyzed in the area of computer equipment was software used. Two areas were examined, custom and commercial software. A total of 118 businesses reported using some type of custom software. Of these businesses 77.1 percent reported using software written for their particular business and 22.9 percent reported using software written for their type of businesses (i.e. inventory program for a grocery store). Figure 3 shows a comparison of the two classifications of custom software and the two classifications of commercial software. Note that no business classified as non-manufacturing reported using custom software. Approximately 54 percent of those that used custom software for their particular business were of the service classification.

A chi square test of significance $(4, N=118)=8.89$, $p>.05$ was achieved in the custom software comparison; therefore, it can be inferred that industry types do not use similar type of custom software.

A total of 428 businesses reported using some type of commercial software. Of these 35.7 percent reported using single task type software (i.e. dedicated word processing program) and 64.3 percent reported using multiple task software. Service type businesses used 46 percent of the single task software. A chi-square test of significance 14 , $N=428)=12.06, P>.05$ was calculated; therefore, it can 
be inferred that businesses do not use similar types of commercial sof tware.

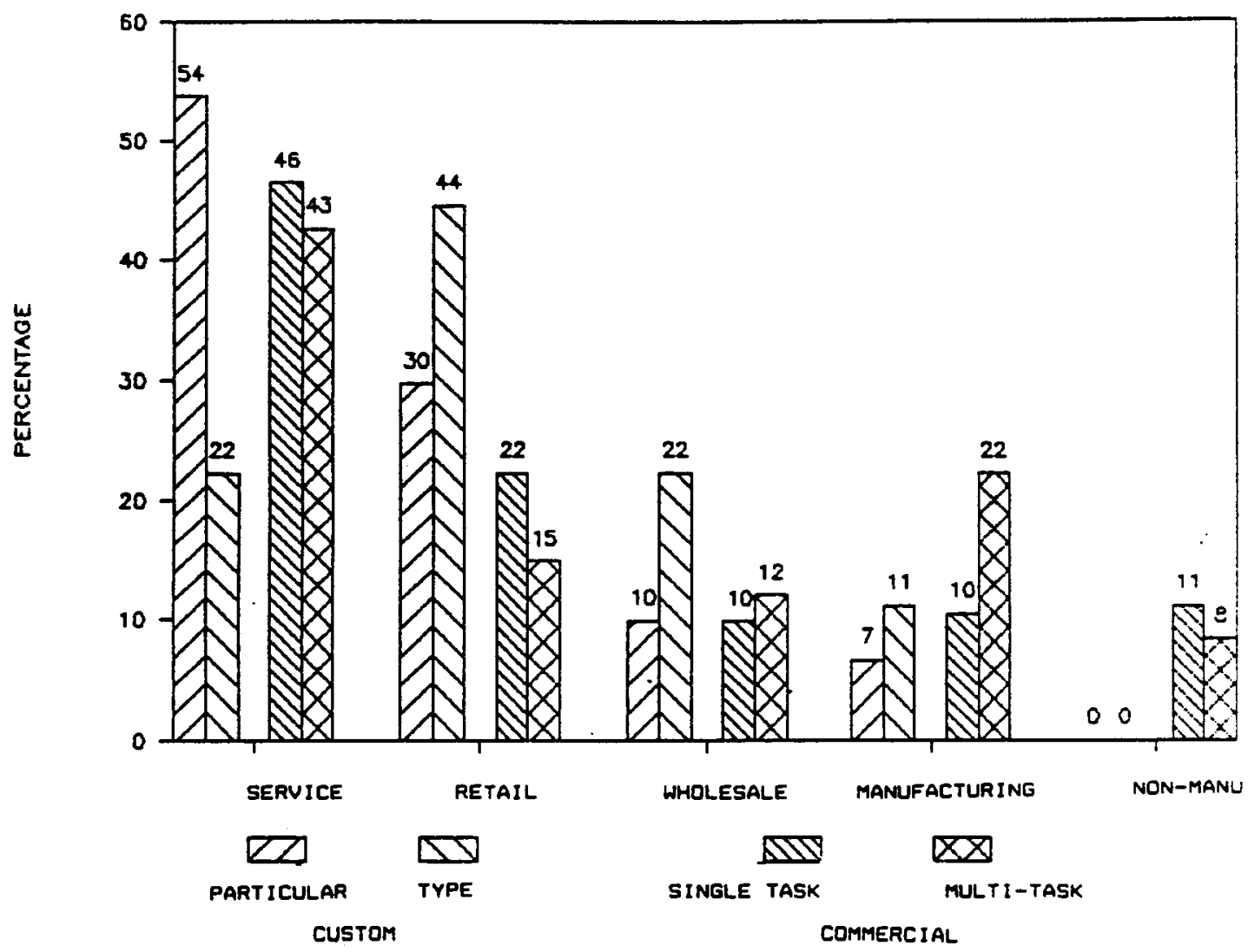

Fiqure 3. Types of software 
COMPUTER TASK

Analysis of the use of computer equipment by task was grouped into six major areas: accounting, word processing, marketing, records management, financial planning, inventory and data base handling. Figure 4 shows this consistency. Approximately 89 percent of service businesses used computers for at least one accounting task.

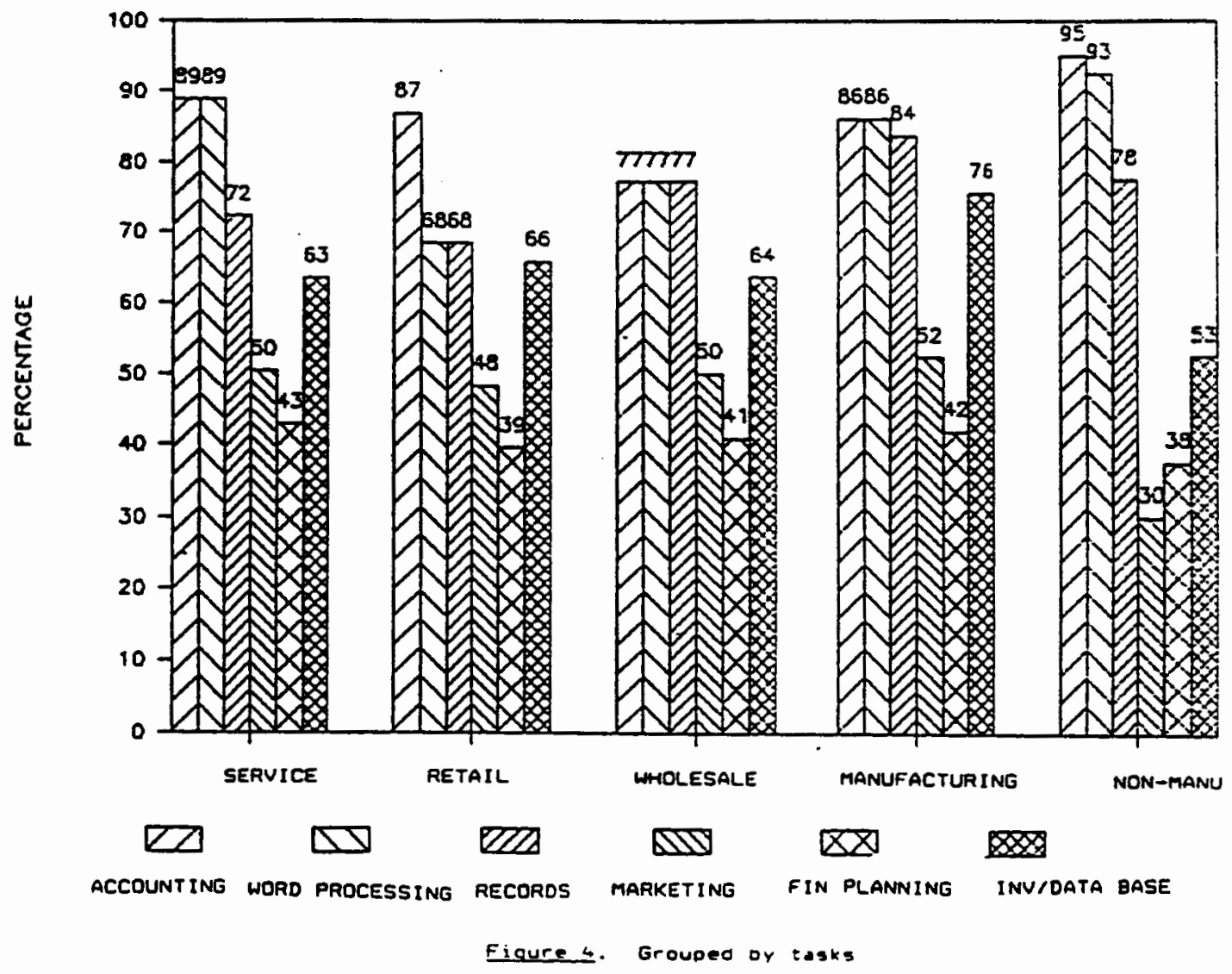

A Kruskal-Wallis 1-Way Analysis of Variance was calculated and a chi-square test of significance ( 24 , $N=35)=.38, P>.98$ was achieved. Based on this high confidence rating, it can be inferred that different 
industry types use computers for similar general tasks as grouped. However, a look at the particular tasks yields different results.

\section{Accounting}

The accounting tasks were divided into seven areas: accounts receivable, general ledger, payroll, financial statements, accounts payable, tax preparation and amortization. Approximately 53 percent of businesses that used the computer systems for accounts receivable and 80 percent that used the computer systems for general ledger were service type businesses. Fiqure 5 illustrates graphically the percentage breakdown of the accounting uses by industry type.

A total of 486 responses were received. A business may have responded positively to all the types of uses. The comparison was conducted with the total number of tasks divided by industry type. A chi-square test of significance $(24, N=486)=135.01, P>.001$ was calculated. No significant similarities in the type of accounting tasks was found.

Word Processing

The word processing tasks were divided into seven areas: forms, editing, composing, grammar/spell checks, high speed document reproduction, calendar and electronic 


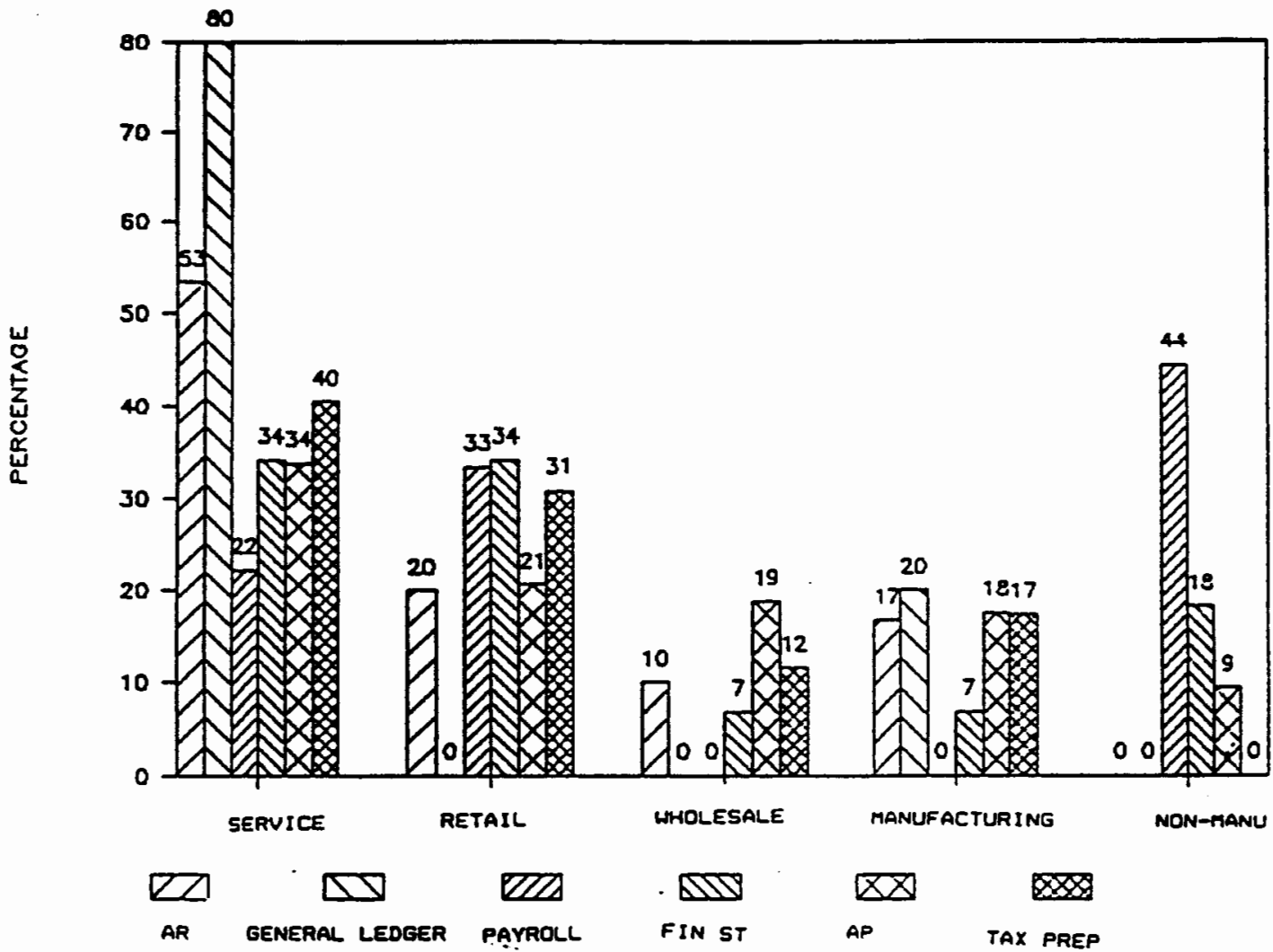

Finures. Azcounting

mail. Approximately 36 percent of businesses that used the computer systems for form processing and 79 percent that used the systems for electronic mail were service type businesses. Figure o shows the percentage of each industry type by word processing task.

A total of 464 responses were received. The most common uses were electronic mail, composing and grammar/spell checks. A chi-square test of significance $(24, N=464)=110.20, P>.001$ was calculated. No significant similarities in the type of word processing can be inferred. 


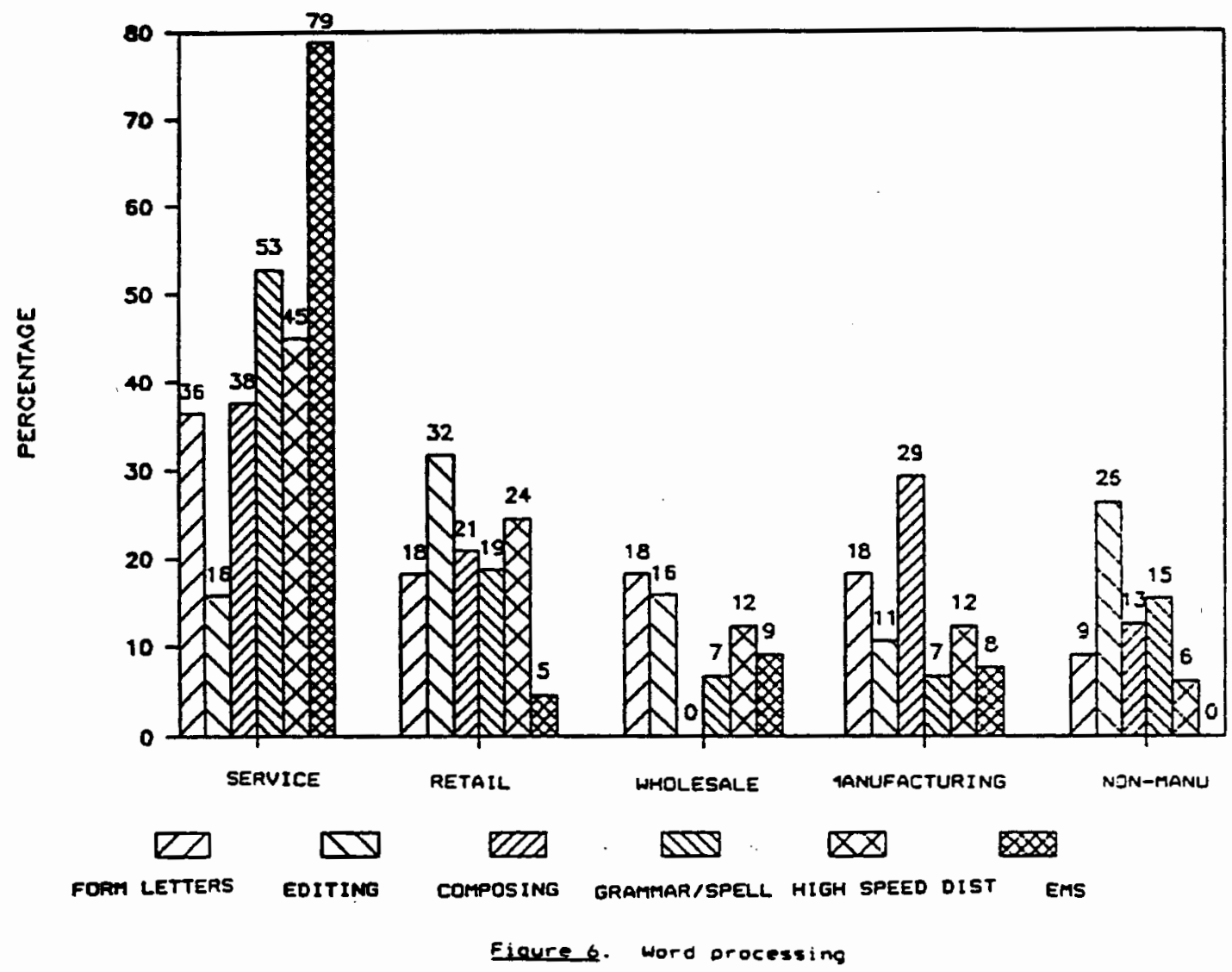

\section{Records Management}

The records management tasks were divided into three areas: personnel information files, customer records and staff scheduling. Approximately 46 percent of businesses that used the computer systems for personnel information files and 60 percent that used the systems for customer records were service type businesses. Figure 7 shows the percentage of each industry for each of the three tasks.

A total of 414 responses were received. Well over half the businesses that reported in this area, used the systems for customer records (280). A chi-square test of 
significance $(8, N=414)=40.64, P>.001$ was calculated. No significant similarities in the type of records management can be inferred.

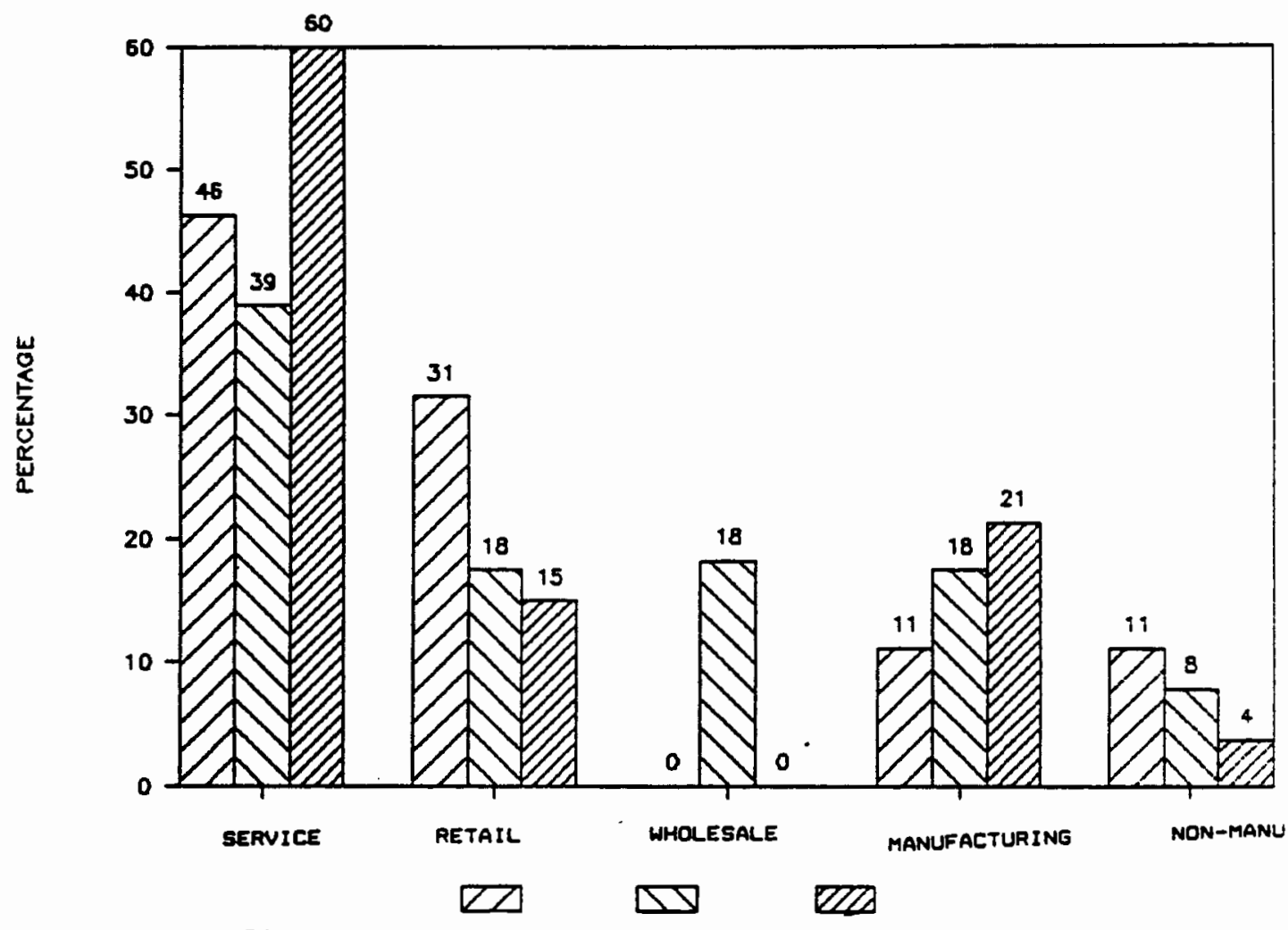

PERSONNEL INFORMATION STAFF SCMEDULING CUSTOMER RECORDS

Fiqure?. Hecords management

Marketing

The marketing tasks of a business were divided into three areas of computer use. They were advertising, sales forecast and communication. Approximately 37 percent of businesses that used a computer system for advertising and 39 percent that used a system for sales forecast were service businesses. Figure 8 shows the percentage of each industry for the three marketing tasks. 


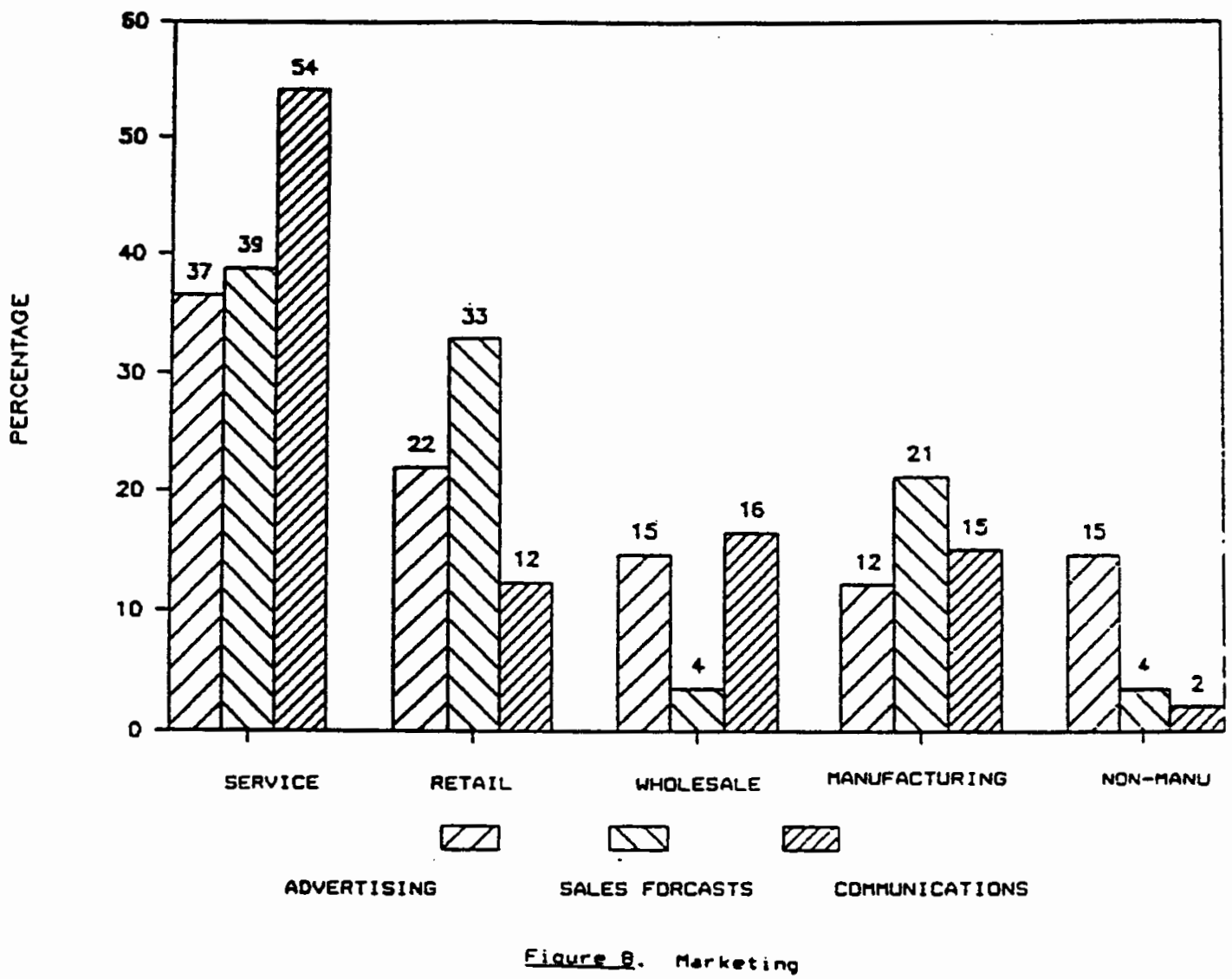

A chi-square test of significance $(8, N=272)=36.20$, P>.001 was calculated. No significant similarities in the type of marketing tasks can be inferred.

Financial Planning

The financial planning tasks were divided into three areas of computer use. They were cash flow, tax planning and stocks and commodities. Approximately 42 percent of businesses that used the computer systems for cash flow and 57 percent that used the systems for tax planning were service businesses. Figure 9 shows the percentage of each industry type for the three categories. 
30

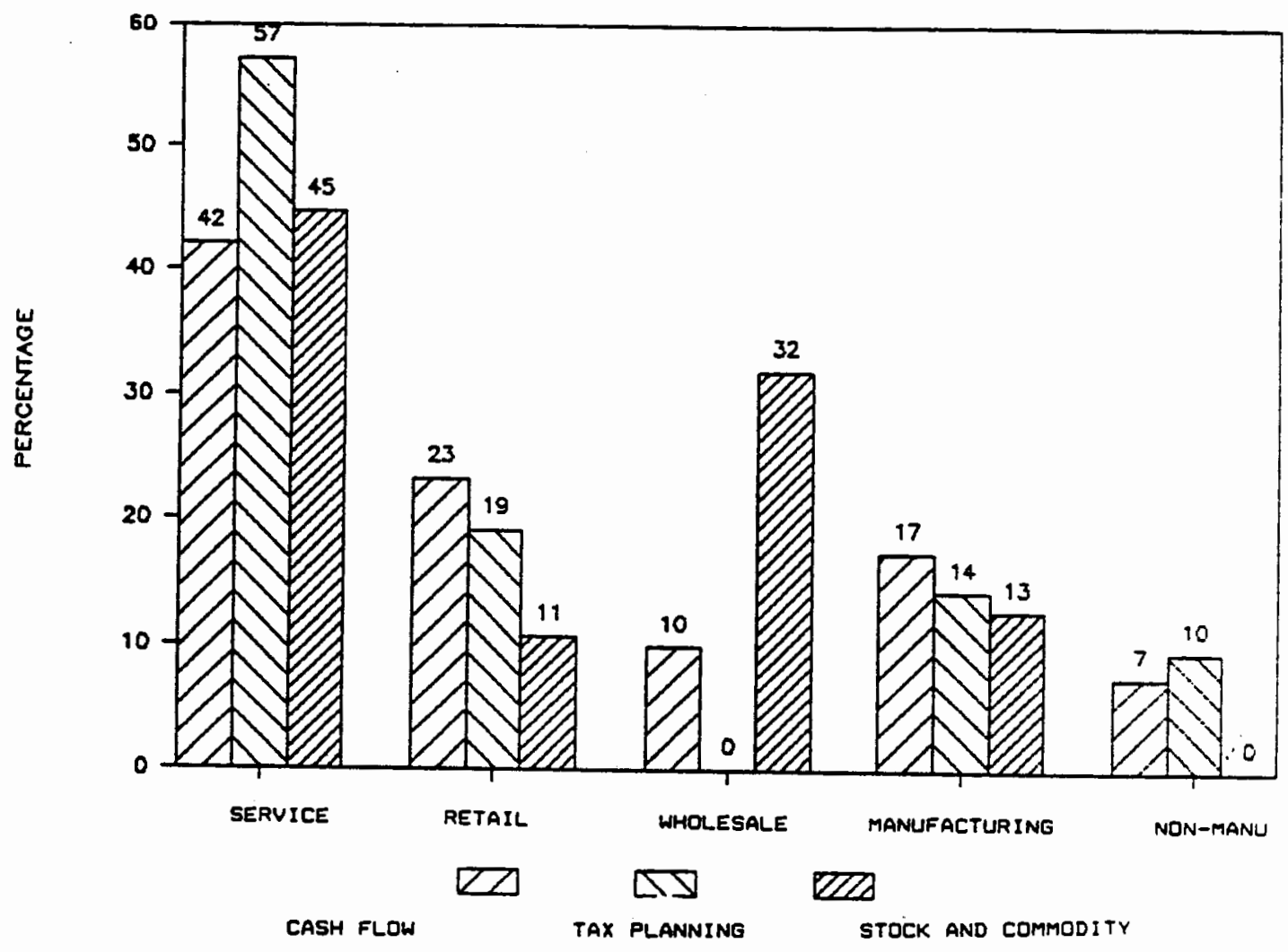

Figure 9. Financial planning

A chi-square test of significance $(B, N=231)=33.57$, P > .001 was calculated. No significant similarities in the type of financial planning task can be inferred.

Inventory and Data Base Handling

This area was divided into inventory, order entry, sales order preparation, billing, purchase order preparation and data base access. A total of 406 responses were received in these areas. The most common use was database access (224). Approximately 49 percent of businesses using the computer systems for database access were service 
businesses. Table 13 shows the percentage each type of business reported for the categories.

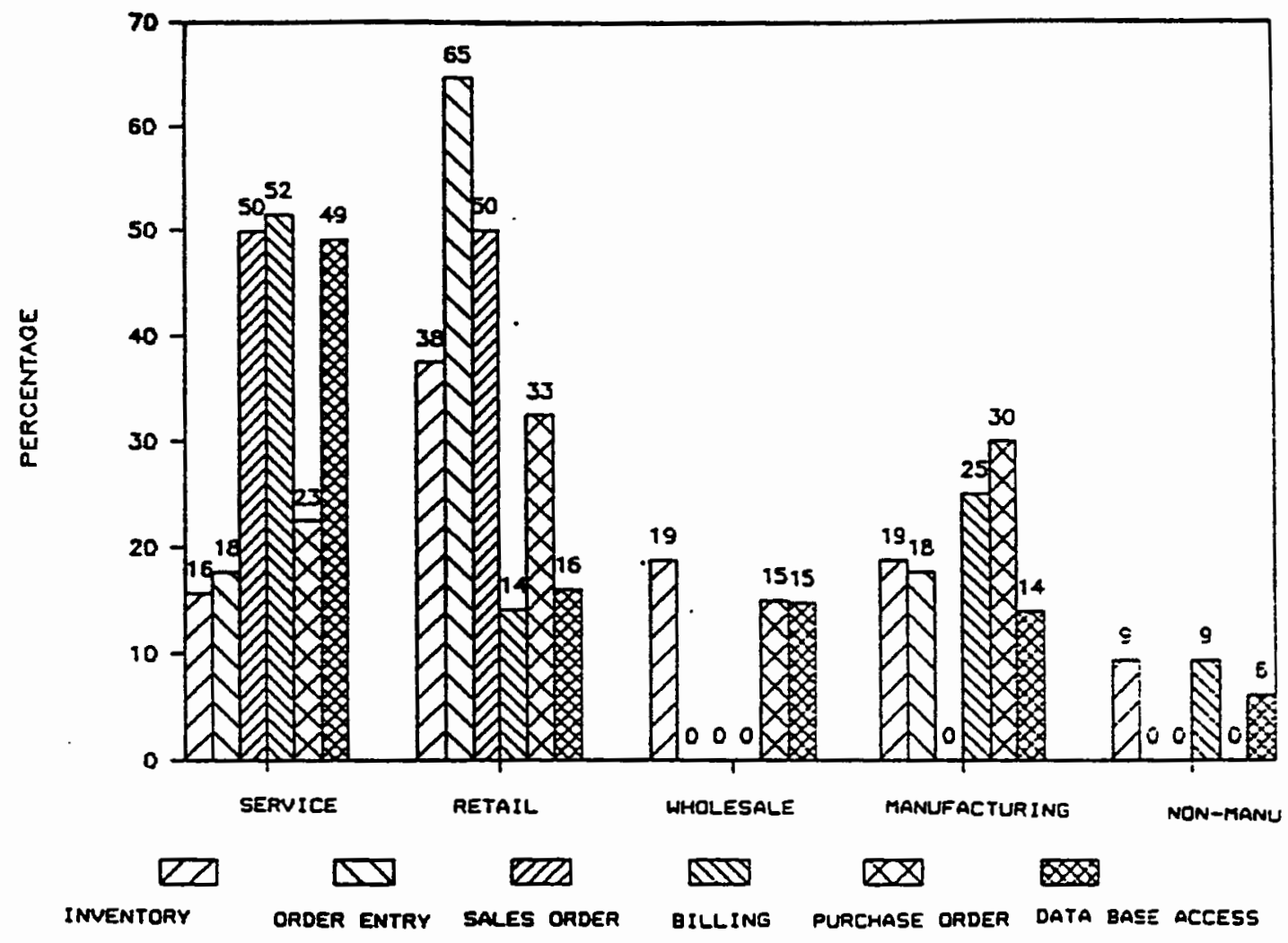

Eigure 10. Inventory and data base nanding

A chi-square test of significance $(20, N=406)=$ 107.34, $p>.001$ was calculated. No significant similarities can be inferred.

A few tasks did not fall under the categories above. Computer systems were used in twenty firms for amusement, eighteen firms for instruction, four firms for insurance, three firms for ticketing, three firms for contracting, and one firm for automated phone dialing. No comparisons were made of these tasks. 
TRAINING PROVIDED COMPUTER OPERATORS

Respondent firms indicated they employed a total of 3,930 computer operators. The mean was slightly above 7 operators per firm. The most common number (mode) of operators was 2. Businesses responding ranged from 1 to 70 operators.

\section{Educational Background}

The first question in the area of training was that of computer education background. The four responses included no formal computer education, course work at the secondary level, course work at vocational schools and course work at a post secondary institution. Repondents representing 974 operators did not respond to the educational background question. Figure 11 shows by percentage the comparison of educational background by industry type. Approximately 66 percent of those with no formal computer education background and 6 percent who have computer education background via vocational schools are people who work in service businesses.

A Kruskal-Wailis 1-Way Analysis of Variance was calculated with a chi-square test of significance $(16, N=$ $2,956)=.89, p>.92$ It can be inferred that operators in the different industry types have similar educational backgrounds. 


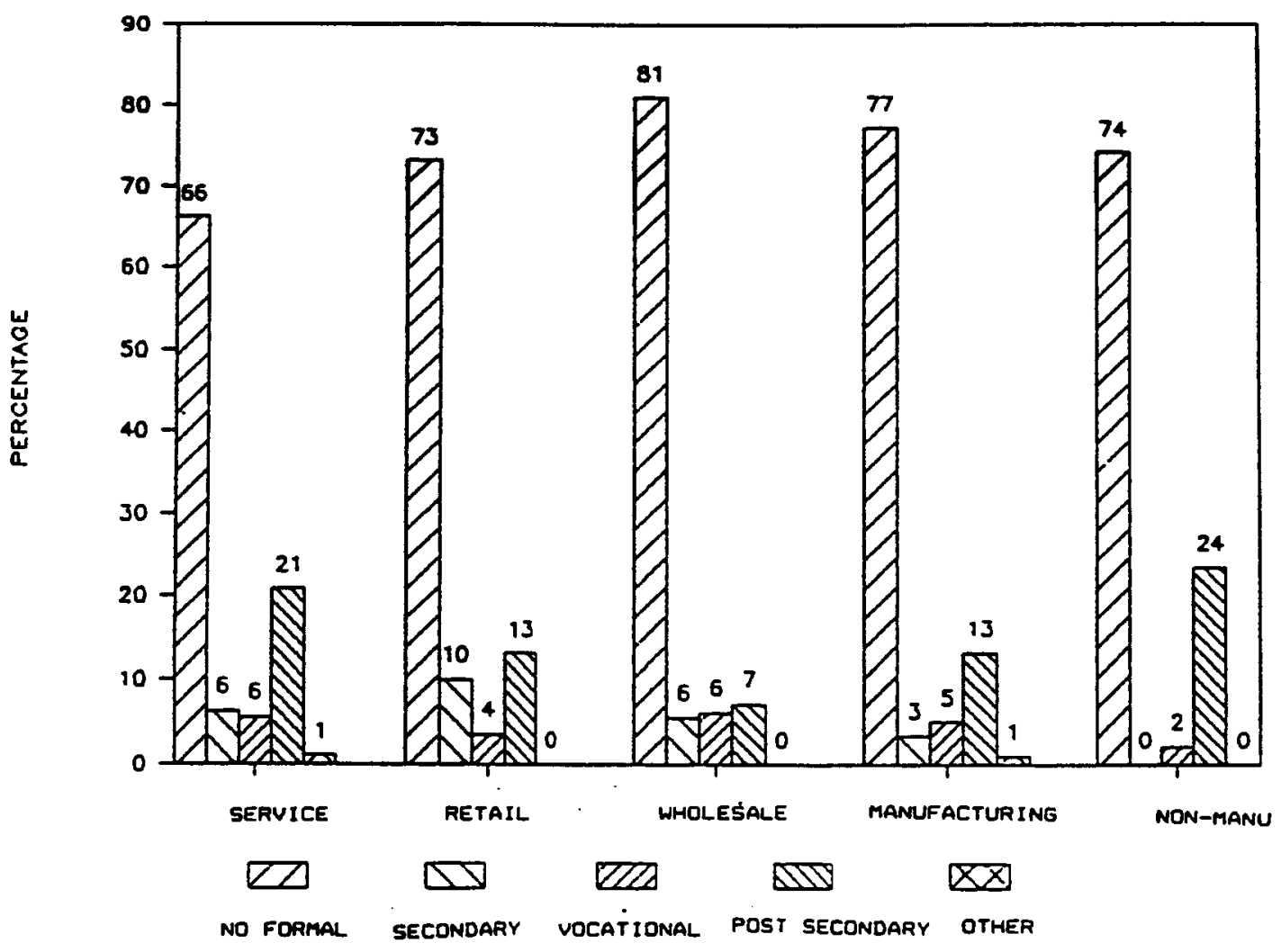

Fiaure 11. Educational background

Specific Training

Training was divided into five categories: self instruction, co-worker trained, trained via short length course (less than 9 hours), trained via medium length course (9-40 hours) and trained via long length course (over 40 hours). Repondents representing 522 operators did not respond to the specific training question. Figure 12 shows by percentage the comparison of training by industry type. Approximately 45 percent of service business operators are co-worker trained. Approximately 35 percent of retail firm operators had training from medium length courses. 


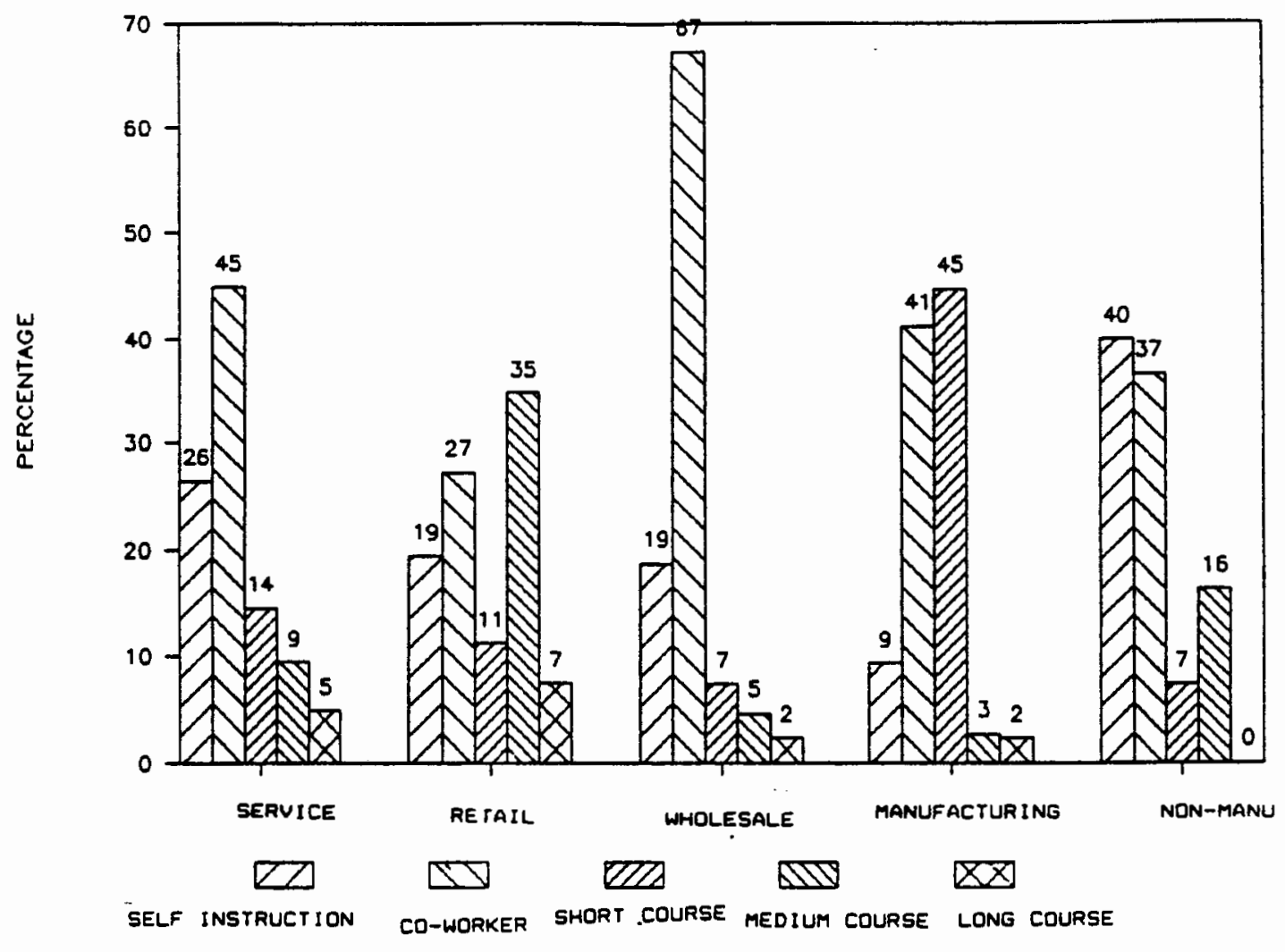

Figure 1e. Specific training

A Kruskal-Wallis 1-Way Analysis of Variance was calculated with a chi-square test of significance (16, $N=$ $3,408)=.58, p>.96$. It can be inferred that operators in the different industry types have similar training backgrounds as classified above.

\section{Instructors of Operators}

The last category analyzed from whom operators receive training. This category was divided into vendor, high school, community college, university, vocational school and other. The "other" category could be used by those who were either self trained or had training different from the other 
five groups. Respondents representing 974 operators did not respond to this question. Figure 13 shows the percentage of operators trained by the various categories by industry type. Approximately 35 percent of service business operators reporting indicated vendor training.

Approximately 43 percent of service business operators were classified in the other category which may indicate a large number of self trained operators.

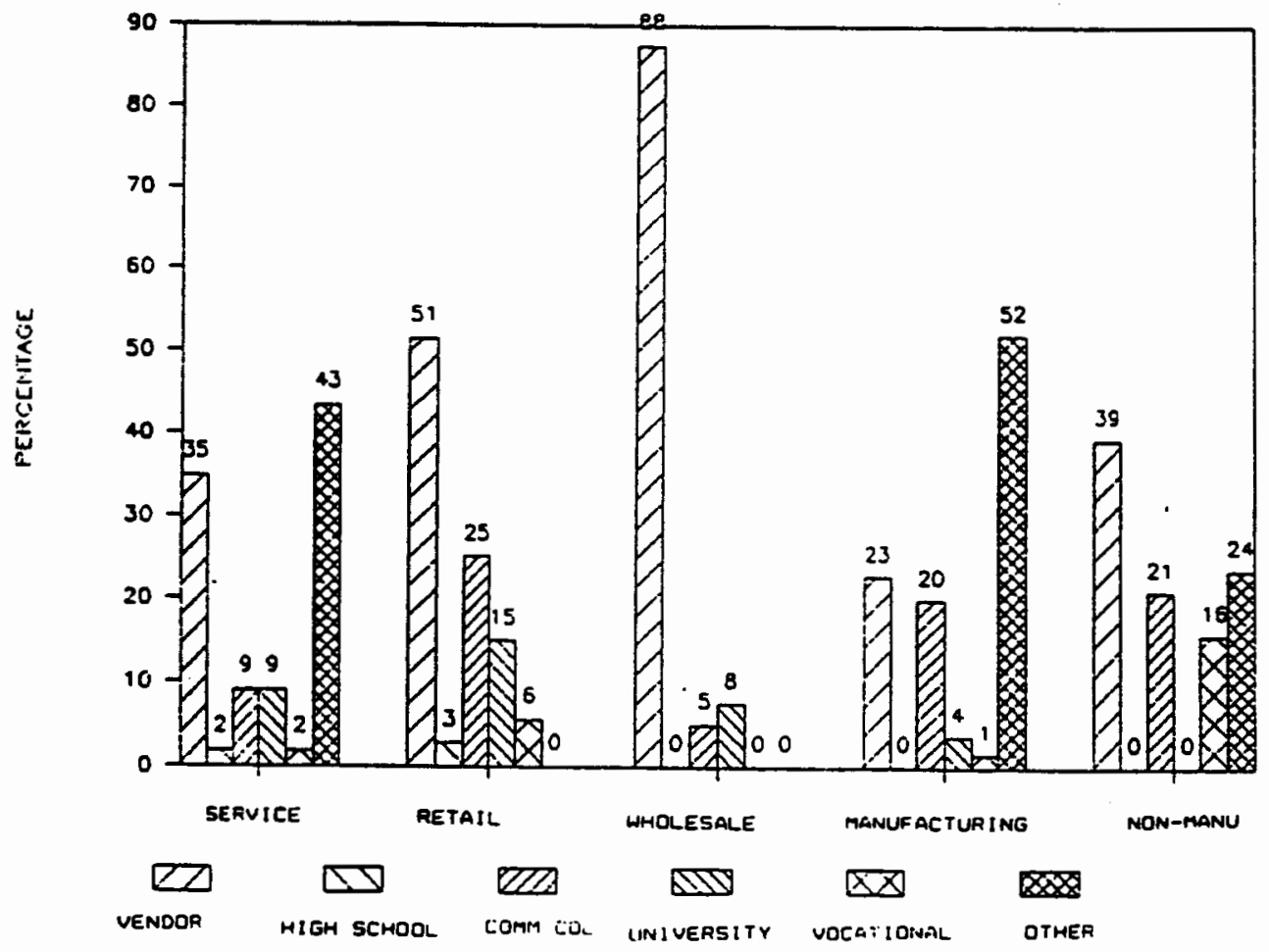

Eigure 13. Instructors of operators

An analysis of variance was calculated with a chisquare test of significance $(20, N=2,956)=1.54, p>.81$. It can be inferred that operators in the different industry types have received similar types of training. 
CONCLUSION AND RECOMMENDATIONS

\section{Rejection of First Hypothesis}

The results of this study demonstrated that different industry types do not use similar size computer equipment and do not use similar brands of computers. This study did not attempt to group computer systems other than by brand name; therefore, no conclusions can be drawn regarding equipment that can use similar operating systems. In the analysis of the software types, different industry types do not use similar classifications of software. Based on these results the first hypothesis, small business industry types in the Portland area use similar computer equipment was rejected.

Rejection of Second Hypothesis

No significant similarities can be inferred from any of the tasks as grouped. The only similarities surfaced when the tasks were grouped together into the six major classifications. Based on these findings the second hypothesis, small business industry types in the Portland area use computer equipment for similar tasks is rejected. 
Acceptance of Third Hypothesis

Computer operators of the different industry types had statistically similar educational backgrounds. The results also indicated similar types of training. The instruction also came from similar sources for the different industry types. All three of the areas analyzed were similar. The third hypothesis that there is no significant difference in the training of computer operators by small business industry types in the portland area is accepted.

\section{Discussion}

A number of questions can be raised in light of the findings presented. In the area of computer equipment it is clear that microcomputers have become the most used computer size. IBM clearly has the highest market share. When the number of IBM machines are added with the number of MS-DOS compatible machines there is no doubt that this operating system is the industries standard. This study did not attempt to analyze this area. The recent development of IBM's operating system 2 (OS/2), has sent many of the copy cat firms scrambling. The question can now be raised has the $0 \mathrm{~S} / 2$ become the new industry standard? If not, will it? This question is one on which further research is needed. The implications for software writers and, therefore, users is immense.

Computers are used in businesses for a variety of tasks. This study revealed that all the industry types use 
computers for tasks such as accounting and word processing. This study did not attempt to look at the less common uses, those that might be considered innovative. This might be an area of growth for software writers. Firms who do not use computers may be able to benefit from software written for the uncommon tasks.

This study did not attempt to study reasons for business use of particular computer systems. Not all small business can make use of computers. Not all small

businesses who can make use of computers want to make use of them. The whims of small business people is an interesting and provocative question.

Industry types have similar training backgrounds. Should they have similar training? They are different industries. Perhaps the training offered is not flexible for businesses. Perhaps educational institutions and training centers should further diversify for different industries.

On the contrary, perhaps all computer operators need a certain type of basic training. If this is the case, should operators have a common training ground. High school training was one of the least reported training areas, perhaps this is a vocational area that should be developed further by community schools. This may be an additional direction for further research. 
No attempt was made to determine what was taught in the specific courses. The curriculum of these courses is another area for futher research.

Lastly, no attempt was made to identify or evaluate the success of the training. If the highest success rate is self training, then perhaps it is a tremendous waste of time and money to seek other training. If the success rate of self training is low, then perhaps it is a tremendous waste of time and money not to seek other training.

The computer world is in its infancy, changes are occurring rapidly. Research in the areas mentioned can benefit society as a whole and small businesses in particular.

Recommendations for Further Research

Further related research is needed in a number of areas. Additional research in the area of compatible machines in one such area. Another area might include a study related to the less common uses of computer systems. Reasons for selection of computer systems should be studied fur ther.

In the educational area, further research is needed into the need of training courses, curriculum of training courses, as well as the effectiveness of the courses. Community schools should study the need for vocational training in their region. 
Summary

This study identified the current uses of computers and training provided operators by a representative sample of small businesses in the Portland area. Comparisons were made by industry type. Data were gathered via questionnaires. The data were analyzed in the three areas. These areas were computer equipment, uses of computer equipment, training on computer equipment. This study found that different industry types did not use similar computer equipment and did not use equipment for similar specific tasks. Different industry types did use computer equipment for similar tasks when grouped into broad areas. Computer operators in the different industry types receive similar types of training. 


\section{SELECTED BIBL IDGRAPHY}

1. Blumenthal, Karen. Tandy's Seagull Guides Computer Unit Into Unexplored Small Business Market, Wall Street Journal, February 1 , 1985 .

2. Blunbell, Greggory S. Micorcomputer Market Soars on All Fronts, Data Communications, December 1982.

3. Canning, Richard C. \& Leeper, Nancy C. So You Are Thinking About a Small Business Computer, Englewood Cliff, New Jersey: Prentice Hall, 1982.

4. Chruch, Dije D. Microcomputers Applications for Small Buiness, Business Education Forum, Detober 1983, PP. 20-2.

5. Dellow, Donald A. A community College Response to a Campus-wide Need for Computer Literacy, Chipola Junior College, Florida, January $30,1985$.

6. Dockter, DuWayne L. Microcomputers in Business: How Are They Being Used?, Journal of Business Education. November, 1984 , pp 63-6.

7. Dologite, Dorthy, Small Computers for Business: A Micro Lab Case History, Journal of Data Education, Winter B4-85. pp. 2-3.

8. ECD Northwest, Ltd. Field Testing Selected Micro

Computer Software, Helena, Montana, June 15, 1984.

9. ECD Northwest, Ltd. Using Personal Computers to Promote Economic Development, Helena, Montana, June 15, 1984.

10. Everk, Stephen F. A Monumental Vear, Manaqement World, November 1984 , Pp. 8-10.

11. Fraiser, James R. Surveying Private-Sector Employers to Identify Labor Training Needs, American Educational Research Association, March 31, 1985. 
12. Heath, Betty. Microcomputers in Small Business Management, National Center for Research in Vocational Edueation, 1984 , p. 106.

13. Heise, Jan. Personnel Acceptance, Management Understanding Are Success Factors Says Small Computer Turnkey, Data Management, November 1980, PP. $26-9$.

14. Hillary, John. Accountants and Small Business Systems, Management Accounting, March 1983 , p 38.

15. Katz, Marty. Small Business Stumbles into Computer Age, Business Week, Dctober 8, 1984, pp. 126,130.

16. Kearsley, G. Computer Literacy in Business and Industry, Educational Technology, July 1982 , pp. 9-14.

17. Kellie, Leslie. Small Business Big Training Needs, Training and Development Journal, June 1984 , PP. $36-42$.

18. Kneale, Dennis. PC Owners Get Tax Break, Wall Street Journal, May 28, 1785.

19. Lehman, Carol M. An Investigation of Current Practices of Personal Computer Utilization in Accounting, Legal, and Medical Firms with Implications for the. Business Education Curriculum, A Journal of the National Association for Business Teacher Education, 1985 , PP. 21-5.

20. Mason, Janet. PCs Dig In, Management World, November 1984 , PP. B-10.

21. Mark, Ken. The Entrpreneurial Explosion, Canadian Business, November 1983, PP. 14-5.

22. McKendrick, Joesph. An SBC in Every Office, Manaqement World, November 1984, PP. 14-5.

23. McKendrick, Joesph. Computers Move up to Management, Management World, November 1983 . PP. 18-9.

24. Randal1, Robert D. Microcomputers in Small Business, Englewood Cliffs, New Jersey: Prentice-Hall, Inc., 1982 .

25. Rosenberg, Marcy. Independents Tackling Training Support, Computerworld, December $31 /$ January 7 , 1980 , PP. 11,14 . 
26. Sanders, Donald H. Introducing Computers to Small

Business, Park Ridge, Illinois: Data Processing Management Association, 1966.

27. Scannell, Tim. Users Seen Skimping of Staff Training, Computerworld, December 17, 1979, pp. 53,56.

28. Schwadel, Francine. Angents for Change, Wall Street Journal, May $20,1985$.

29. Servino, Elizabeth $F$. What is a Samll Business Computer?, Data Management, November 1980 , pp. 8-12.

30. Turner, J.A. 15 Colleges Ask for Common Disk Dperating System, Chronicle of Higher Education, July 1984 , p. 12 .

31. Uhlig, George E. Microcomputers and the Future, Alabama State University, May 12, 1984.

32. Lttal, Bro. Pitching Computers to Small Business, Fortune, April 1, 1985, Pp. 6-9.

33. Welke, Larry A. Sizing Up Software, Management World, November 1984 , p. 11. 


\section{LETTER REQUESTING PARTICIPATION IN STUDY}

Date

The Company

Attention: Mr./Mrs./Ms.

CED

123 Main Street

Portland, OR 972**

Dear Mr./Mrs./Ms.

Computer use by many segments of our society has expanded due to increased availability, improved technology and reasonable costs of computers. However there are still businesses who da not rely on computer because of lack of information, training or availability of applicable sof tware.

You are one of a select number of people who are being asked to complete a questionnaire on this matter. Your name was drawn in a random sample of the members of your profession. In order that the results will truly represent the current practices of the people in business of the Greater Portland Area, it is important that each questioninaire be completed and returned.

The questionnaire will be analyzed by industry types. The results of this survey will be the basis of a thesis paper to be presented at Portland State University. La Salle High School has agreed to cooperate in the project. La Salle will use the summarized results to help determine appropriate curriculum in their computer education program.

You may be assured of complete confidentiality. Your name will never be placed on the questionnaire nor will the mailing list for this survey ever be released to anyone. A copy of the research finding will be available upon request.

Please complete and mail the enclosed response card. If appropriate the questionnaire will be sent on receipt of this card.

If you have any questions, please call me. I will greatly appreciate your prompt response. I look forward to hearing from you.

Sincerely

Don G. Langenhorst

Project Director

Business Phone: 659-4155

Home Phone: 652-2849

Enclosure 


\section{RESPONSE CARD}

Yes, we use computers and are willing to complete the questionnaire.

No. we do not use compurters.

No, we have compurters but are not willing to complete the questionnaire.

Reasona/Comments:

\section{Signimure}

Send Questionnaire to (it different from label):

\section{BUSINESS REPLY MAIL}

Frest Cans Permit No. A - 1379 Portlend OR

POSTAGE WIL BE PAIO BY ADORESSEE

LaSalle High School

c/o Don G. Langenhorst

11999 S.E. Fuller Road.

Milwaukie, Oregon 97222

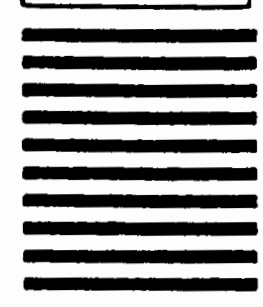


Date

The Company

Attention: Mr./Mrs./Ms.

CED

123 Main

Portland, OR 972**

Dear Mr./Mrs./Ms.

Thank you for your prompt response.

In order that the results will truly represent the current practices of the people in business of the Greater Portland Area, it is important that each questionnaire be completed and returned.

Once again, you may be assured of complete confidentiality. Your name will never be placed on the questionnaire nor will the mailing list for this survey ever be released to anyone. A copy of the research findings will be available upon request.

Please complete and return the einclosed questionnaire.

If you have any questions, please call me. Again, I will greatly appreciate your prompt response. I look forward to hearing from you.

Sincerely

Don G. Langenhorst

Project Director

Business Phone: 659-4155

Home Phone: 652-2849

Enclosures 


\section{Questionnaire}

Directionsi Please check the box and/or fill in the blank on each question. You way check ware than one item on each question.

1. What is the size of computer (s) in use?

- mainframe

- mini (i.e. IBM 38, IBM 32, Wang)

- micro (personal computers)

2. What brand(s) of computer (s) do you use?
- IBM
0 Wang
- Apple
- Hewlett/Packard
- Radio Shack
- Compaqt.
- other, please specify

3. What is/are the model number(s)/name(s) of the machine(s)?

4. What type(s) of software (prograns) do you currently use?

Custom

- Individualized for particular business

- Individualized for type of business li.e. inventory program for grocery store)

\section{Commercial}

- Single task (i.e. word processing or general ledger)

- Milti-task (i.e. Combination word processing \& data base)

5. Please check the tasks for which you currently use the computer( 5 ).

Accounting

- Accounts Receivable

- General Ledger

- Payroll

- Financial Statements

- Accounts Payable

- Tax Preparation

- Anortization schedules

Other, please specify

Hord processing

- Form letters

- Editing

- Composing at terminal

- Grammar and spelling checks

- High speed document distribution 
Word processing (continued)

- Deadline reminder/personal calendar

- Electronic mail

Marketing

Other, please specify

- Advertising

- Sales Forecasts

- Communications

Records

Other, please specify

- Personnel information files

- Customer records

- Staff scheduling

- Other, please specify

Financial Planning

- Cash flow

- Tax planning

- Stock and commodity

Other, please specify

Other

- Inventory

- Order entry

- Sales order preparation

- Billing

- Purchase order preparation

- Instruction

- Amusement

- Data base access

- Other, please specify

6. How any people operate computers in your firm?

:Questions 7-9, please 1 ist the number of employees that qualify in the blank next to each of the responses.

7. What computer education background do users have? no formal education

- course work at the secondary level
course work at vocational schools
course work at a post secondary institution
other, please specify

8. What specific training does the user(s) have with current equipment?

self instruction

worker trained

short course (less than 9 hrs., i.e. workshop)

medium length course (9-40 hrs.)

long course (more than 40 hrs.) 
9. If you answered any of the last three items in question no. 8, who offered the course (how many took the course from each).

\begin{tabular}{l} 
vendor \\
high school \\
\hline \\
community college \\
university \\
vocational school \\
other, please specify
\end{tabular}

10. What is the number of operators provided outside training?

Is there anything else you would like to tell about computers in business operations? If so, please use this space for that purpose. 
ALPHA

ALTOS

ATARI

ATLAS

ATT

BASIC 4

BIDTEK

BOUROUGHS XT

CHERRY PC

COLUMBIA 1600-4

COMMODORE

CYBEX

DATA 0.4

DATA GENERAL

DATAPOINT

DEC

DIGITAL RAINBOW, PDP+1

DMC

EAGLE

EPSON

FORTUNE UNIX 32:16

HONEYWELL - LEVEL 6

I BC

IDS

ITT 386

KAPRO

KINITRON

LEADING EDGE D

MAGNUM

MCDONALD

MITAC XT,AT
MORROW CPM

MULTI TECH

NATIONAL SEMI 1700

NCR PCB, 4

NORTH STAR DIMENSION

NSC

OSBORN

PACKARD BELL

PANASONIC

PHILLIPS

PRIME AT

REYNOLDS

ROCKWELL 350

SABRE

SHARP

SPERRY IT 286, 3126

SUCCESS SYSTEMS

TATUNG - TCS 7000

TELEVIDEO

TELEX

TRIAD

TWIN

TYPSETTER

VAR I TYER

VAX 785

VICTOR 9000

VISUAL

WYSE

$X$

ZENITH 